\title{
Approaches Affecting Current Account in the Balance of Payments
}

\author{
Teuta Ismaili-Muharremi* \\ Senior Statistician at Central Bank of the Republic of Kosovo and \\ $\mathrm{PhD}$ candidate at the Doctoral School - European University of Tirana
}

\section{Doi:10.5901/ajis.2015.v4n3s1p417}

\section{Abstract}

This paper tries to elaborate on difficulties and challenges of the Western Balkan countries, that all seems to have problems with regard to the sustainability of their current account. After providing some insight about main approaches used for analyzing the balance of payments in general, this paper focuses on outcomes of variety of crisis and it tries to give some understanding on key elements that influence the balance of payments stance. Current account deficit seems to be attractive for analysis for quite some time and in that regard we find variety of approaches used. The paper provides brief information on methodologies used by different authors in attempting to answer the question about essential drivers of the developments in the current account.

Keywords: Balance of payments, approaches in assessing current account deficit, financial account, financing.

\section{Introduction}

The balance of payments reflects in the best way the quality of a country's economy in particular towards the outside world.

In order to evaluate the problems of the current account deficit to Kosovo, these research objectives will be taken into consideration:

To understand the nature, history and the importance of current account problems in Kosovo;

To present a clear understanding of the major problems that cause the deterioration of the current account deficit;

To make a review of the current account deficit;

To present the importance of capital inflows from abroad in Kosovo;

Based on the these analyzes to draw conclusions and recommendations to mitigate current account deficit in Kosovo.

\section{Theoretical Framework}

The current account balance measures the evolution in net foreign assets in the economy as a result of economic relations between resident and nonresident entities. In this context, all authors emphasize specifically the importance of identifying the level of sustainability of the current account deficit.

One should be careful when analyzing the current account deficit especially with regard to the call for introduction of certain policy changes. In other words, the current account deficit maybe an outcome of temporary external shocks and in this case it will not require significant policy changes that are necessary for example in the case when the deficit is an outcome of continuous foreign borrowing or reduction of international reserves.

Having said that we see that the question of sustainability of the current deficit remains as an multifaceted issue that can not be solved through a simple answer.

The concept of sustainability of the current account balance is very complex and there is no simple answer to the question.

What is the level of the sustainable of current account deficit . By Roubin and Wachtel (1998) "There is no simple rule that can help us determine when a current account deficit is sustainable or not", because what is sustainable for one country, might not be for another. In other words, current account sustainability depends on a country's specifics. i.e: Roubini and Wachtel (1997) explicitly analyzed the sustainability of the current account in the transition countries where they concluded that the analysis of the the CA's imbalances is not easy because of the problem that has concerns with:

Lack of appropriate data and reliable (especially those that have to do with national accounts, movement of capital, etc.), on the other hand.

Difficulties in interpreting the data as a result of more rapid development of these countries. Modern literature on 
the sustainability of the current account deficit is strongly influenced by the theoretical work of Milesi-Ferretti and Razin, who consider the current account deficit to less sustainable if they are high in relation to GDP if they are due to lower domestic private savings than investment activities, and if they are accompanied by a low level of national savings.

Milesi-Ferretti and Razin (1996), who point out that "current account deficits above 5\% of GDP should draw attention, particularly if the deficit is financed by short-term debt or by foreign exchange reserves, and if it reflects high consumption spending".

Milesi-Ferreti dhe Razin (1996), Roubin \&Wachtel (1998) suggest that,to analyze the sustainability of the current account deficit, it is necessary to consider these factors: the cause of the current account deficit, structure of current account, structure and volume of inflows of foreign capital, the level of economic growth ,assessment of real exchange rate, structure and level of external debt, the level of foreign reserves, financial system stability, openness of the economy, macroeconomic and political stability and global factors.

The current account deficit is a useful signal to policy makers and throught policy measures to seek to induce changes to the current account balance.

For assessing the concept of sustainability of current account, have been developed different approaches. In addition, the views of economist about the consequences of the current account deficits have changed through i.e. Edwards (2001), in the area of the views important changes of economists on the subject: from "deficits matter," to "deficits are irrelevant if the public sector is in equilibrium," back to "deficits matter," to the current dominant view" current deficits may matter."

Many of the changes have resulted from important crisis situations in advanced and emerging economies. Edwards, (2001) concludes for the large current account deficits, highlighting that the evidence provides a rather strong support for the view that, from a policy perspective, those deficits should be a cause for concern, only when there is a large current account deficit a crisis can take place.

One of the approaches analyzes the sustainability through the inter-temporal budget constraints.. Thus, a deficit in the current account is the result of a balance between domestic savings and investment which reflect the increased activity of the investment which exceeds domestic savings

or with growth consumption, which results in the accumulation of debts that cannot be managed carefully.

According to these models given by Obstfeld and Rogoff, the current account depends on deviations of the output, consumption, government spending and world interest rate from their "permanent" levels, as well as of the country's net foreign asset position.

A drawback of these models is that they failed to give a national explanation for the current account behavior.

It should be noted that the calculation of the sustainability of the current account deficit has some limitations.

\section{Mesurment of Current Account Deficit for Western Balkan Countries}

In the case of Western Balkan countries the main cause of the current account deficit appears to be the deficit of the foreign trade balance, as can be seen in the table 1. A deficit in the current account is considered less sustainable if it is a consequence of the deficit of the balance of foreign trade, and high trade deficits point to the existence of serious problems of competitiveness of the economy, and the insufficient inflow of foreign currency into regular basis to face export activity that comes to the submission of the question in relation to the country's ability to service external debt in the future. After the liberalization of foreign trade, Kosovo is facing with a permanent trade deficit, which reflects the lack the competitiveness of it's exports. Furthermore for sustainable economic development in the future period Kosova needs healthy economic growth based on increased levels of investment and productivity.

Table 1. Structure of the total account for Western Balkan Countries

\begin{tabular}{|c|c|c|c|c|c|}
\hline \multicolumn{7}{|c|}{ Current Account of Western Balkan Countries } \\
\hline Period & Current Account & Goods & Services & Primary Income & Secondary Income \\
\hline 2008 & -13136.91 & -21350.43 & 1247.85 & -366.30 & 6978.92 \\
\hline 2009 & -5834.93 & -16066.46 & 1994.22 & -108.94 & 7936.89 \\
\hline 2010 & -5206.73 & -15254.11 & 2109.31 & -591.91 & 8059.16 \\
\hline 2011 & -7585.90 & -17275.07 & 2585.27 & -1274.21 & 7903.06 \\
\hline 2012 & -7059.20 & -17421.12 & 2710.74 & -990.30 & 8152.11 \\
\hline 2013 & -4840.05 & -15046.36 & 2772.54 & -1159.91 & 8129.19 \\
\hline
\end{tabular}

Source: Based on data obtained from the web sites of the central banks, in millions of euro. 
In Kosovo the high level of imports is the main features which results in a high trade deficit, then the primary incomes and secondary incomes what means that here the main role have remittances that contribute directly to the degree of coverage of the current account deficit and it is about a higher sensitivity of the sustainability of the current account from level of remittances, while at the financial account exists high dependence from foreign direct investment.

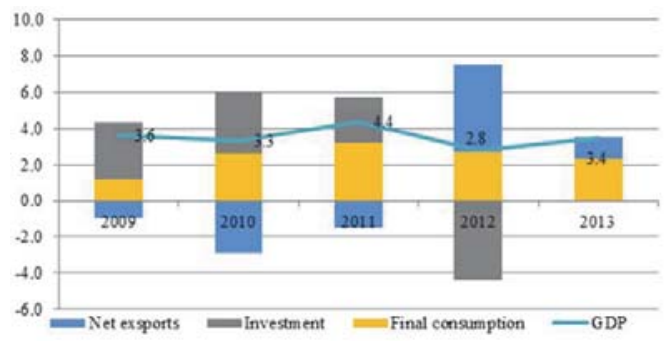

Figure 1. Contributions to Kosova's y-o-y growth rate by expenditure (percentage points)

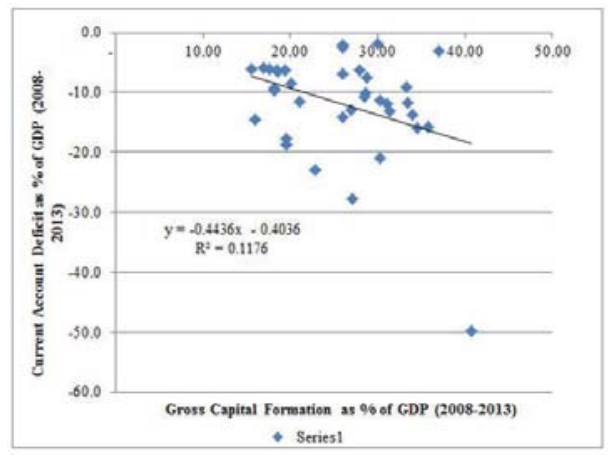

Figure 2: The relation between gross capital formation and current account deficits for Western Balkan Countries Source: Author's calculation based on online data from Unctad, World Bank \& IMF.

Due to the savings income still low, the gross capital formation in the countries of South-Eastern Europe is financed partly from foreign sources of capital (foreign direct investments and financial investments). It is clear from Figure 1, which shows that an increase of 1 percentage point of GDP in gross domestic capital is financed by foreign capital at the rate of $44 \%$ ( which means 0.44 percentage financed by foreigners. If we refer to literature, before the global crisis the part of financing from foreign gross capital of these countries it was significantly higher and amounted to $77 \%$.

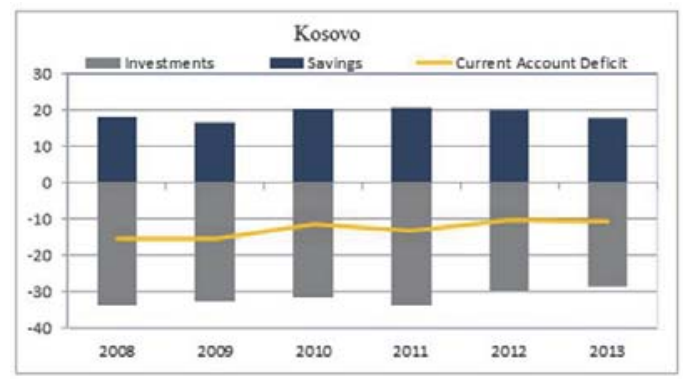

Figure 3: The Savings, Investment and current account balance, as \% of GDP

Source: Author's calculation based on data from Kosovo Agency of Statistics \& Central Bank of the Republic of Kosovo. 


\section{Conclusion}

Kosovo's economy continues to be highly dependent on the flow of revenues in the account of BP and the capital, especially the income generated by kosovars living abroad (remittances, travel services, FDI diaspora).

The above mentioned categories represent the main sources of funding used to import, then financial development and to generate economic growth.

The risk of trade deficit for the economic stability of Kosovo is elaborated in other studies such as Korovilas (2002) which underlined the need for the use of local resources and the growing export of Kosovo.

Reliance on exports of natural resources and / or goods processed as raw materials can not guarantee the reduction of the gap in the trade balance, respectively unable to ensure the sustainability of this balance and increase productivity and thus of new places of work.

In essence, a diagnosis fairly detailed economic growth and employment policies we can find in the paper of Sen and Kirkptarick (2011) which elaborating in the Kosovo case call for improvements in the cost and access of financing, then that of exploiting the benefit of the public good and especially necessary improvements regarding the rule of law.

\section{References}

Milesi-Ferretti, Gian Maria and Assaf Razin. 1996. "Sustainability of Persistent Current Account Deficits." National Bureau of Economic Research Working Paper No. 5467.

Korovilas,P.J. (2002), The economic sustainability of Post-conflict Kosovo, Post-Communist Economies, 14(1), p.109 - 121.

Reinke, J., „Remittances in the Balance of Payments Framework: Current Problems and Forthcoming Improvements" ( The Center of Excellence in Finance, Ljubljana, Slovenia, February 26 to March 2, 2007).

Rogoff, K. (1996) 'The purchasing power parity puzzle', Journal of Economic Literature, 34 (2):647-68.

Srđan Boljanović, Economic Annals, Vol. LVII, No. 195 / October - December 2012 UDC: 3.33 ISSN: 0013-3264

Stiglitz et al (1993) The role of the state in financial markets, World Bank Research Observer, Annual Conference on Development Economics Supplement.

Edwards, S. (2001) "Does the current account matter?", NBER Working paper No.8275.

Unevsca, D.and Jovanovic, B. (2011) "Sustainability of the Macedonian Current Account" Working Paper, June 2011.

Rogoff, K. (1996) 'The purchasing power parity puzzle', Journal of Economic Literature, 34 (2):647-68.

Lothian, J.R. and L. Wu (2011) 'Uncovered interest-rate parity over the past two centuries', Journal of International Money and Finance, 30(3), 448-73.

Burda, M. and C. Wyplosz (2009) Macroeconomics, A European Text, 6th edition, OxfordUniversity Press, Oxford.

Ostry, J.D., A.R. Ghosh, K. Habermeier, L. Laeven, M. Chamon, M. S. Qureshi and A. Kokenyne, 'Managing Capital Inflows: What Tools to Use?', IMF Staff Discussion Note, April 5, 2011,

Bordo, M.(1999) The Gold Standard and Related Regimes,Cambridge University Press,Cambridge

Bergman, M., S. Gerlach and L. Jonung(1993) 'The rise and fall of the Scandinavian currency union 1873-1920', European Economic Review, 37: 507-17.

Bordo, M. and L. Jonung(2000) Lessons for EMU from the History of Monetary Unions, Institute of Economic Affairs, London.

Holtfrerich, C.L.(1993) 'Did monetary unification precede or follow political unification of Germany in the 19th century?', European Economic Review, 37: 518-24.

Eichengrenn, B.(2007) 'Sui Generis Euro'www.econ.berkeley.edu/ eichengr/sui_generis_EMU.pdf.

Kenen, P.B.(1995) Economic and Monetary Union in Europe, Cambridge University Press, Cambridge.

Padoa-Schioppa, T.(2000) The Road to Monetary Union in Europe: The Emperor, the Kings, and the Genies, Oxford University Press, Oxford.

Babecký, J. et al (2012), Banking, Debt, and Currency Crises - Early Warning Indicators for Developed Countries, Working Papers Series, No.1485, European Central Bank, pp. $1-43$.

Budsayaplakorn, S. et al(2010),Can Macroeconomic Indicators Predict a Currency Crisis? Evidence from Selected Southeast Asian Countries - Emerging Markets Finance \& Trade / November-December 2010, Vol. 46, No. 6, pp. 5-21,

Bruinshoofd. A, at al (2010), Banking Sector Fragility and the Transmission of Currency Crises - RESEARCH ARTICLE Open Econ Rev (2010)

Claessens, S. and Ayhan Kose, M. (2013) Financial Crises:Explanations, Types, and Implications, IMF Working Paper, WP 13/28, pp. 1 $-65$.

Darvas, Z. and Pisani-Ferry, J. (2010) The Threat of 'Currency Wars': A European Perspective, Bruegel Policy Contribution, Issue 2010/12, December 2010, pp.1 - 17. 